\title{
Mechanical Response to Reducing Gases in PZT/ZnO Actuator
}

\author{
Yuji ISOGAI, Masaru MIYAYAMA and Hiroaki YANAGIDA* \\ Research Center for Advanced Science and Technology, The University of Tokyo, 4-6-1, Komaba, Meguro-ku, Tokyo 153 \\ *Department of Applied Chemistry, Faculty of Engineering, The University of Tokyo, 7-3-1, Hongo, Bunkyou-ku, Tokyo 113
}

\section{$\mathrm{PZT} / \mathrm{ZnO}$ アクチュエーターにおける還元性ガスへの機械的応答 磯谷祐二・宮山 勝・柳田博明* \\ 東京大学先端科学技術研究センター, 153 東京都目黒区駒場 4-6-1 \\ *東京大学工学部応用化学科, 113 東京都文京区本郷 7-3-1}

[Received November 1, 1994; Accepted November 22, 1994]

\begin{abstract}
Electrostrictive behavior responding to reducing gas $\left(\mathrm{CO}, \mathrm{H}_{2}\right)$ atmospheres was investigated on a piezoelectric actuator consisting of a dense PZT plate $\left(\mathrm{Pb}_{0.995}\right.$ $\left.\mathrm{Nb}_{0.01}\left(\mathrm{Zr}_{0.53} \mathrm{Ti}_{0.47}\right)_{0.99} \mathrm{O}_{3}\right)$ and a porous $\mathrm{ZnO}$ plate $\left(\mathrm{ZnO}+0.2 \mathrm{~mol} \% \mathrm{Li}_{2} \mathrm{O}+10 \mathrm{~mol} \% \mathrm{NiO}\right)$. The dense PZT and press-formed $\mathrm{ZnO}$ disks were bonded by hot-pressing using glass frits. The PZT side of the actuator showed a shrinkage by a d.c. bias at $250^{\circ} \mathrm{C}$, and its value was larger in reducing gas atmosphere than in air. When measured on the separated plates, the PZT and $\mathrm{ZnO}$ plates had high resistivities in the same level in air but only the $\mathrm{ZnO}$ showed a decrease in resistivity by introduction of reducing gas. It is assumed that the applied voltage is distributed to both plates in air, but concentrated to the PZT part in reducing gas atmospheres due to a decrease in resistance of the $\mathrm{ZnO}$ part. The bending displacement of the actuator was also observed in reducing gas atmosphere, although the precise value was not obtained due to the high temperature in measurements.
\end{abstract}

Key-words : Gas sensor, Piezoelectric actuator, PZT, $\mathrm{ZnO}$, $\mathrm{CO}, \mathrm{H}_{2}$

\section{Introduction}

Piezoelectric actuators have attracted an attention as mechanical devices instead of oil driving devices, electromagnetic valves or motors. Recently, piezoelectric actuators have been used for VTR head actuators, inc jet devices of printers and driving devices of fatigue testing machines etc. The value of bending displacement is usually controlled by the intensity of applying electric field. A monomorph type actuator of PZT single plate was reported to show a change of bending displacement by an increase in humidity, ${ }^{1}$ ) and present authors reported that an unimorph type actuator consisting of a porous and a dense PZT plate shows a bending displacement depending on environmental humidity. ${ }^{2)}$ Such a devise is expected as one of the intelligent materials, which can sense the environmental atmosphere and actuate responding to a change of atmosphere by itself. ${ }^{3)}$ However, it has not yet been reported that a mechanical displacement is controlled by environmental reducing gases.

In the present study, piezoelectric actuator was prepared by stacking a dense PZT plate with a porous $\mathrm{ZnO}$ plate, which was well known as a gas sensing material. ${ }^{4}{ }^{, 5)}$ Its electrostrictive behavior responding to reducing gases was measured at $250^{\circ} \mathrm{C}$.

\section{Experimental procedure}

2.1 Specimen preparation

PZT ceramics $\left(\mathrm{Pb}_{0.995} \mathrm{Nb}_{0.01}\left(\mathrm{Zr}_{0.53} \mathrm{Ti}_{0.47}\right)_{0.99} \mathrm{O}_{3}\right)$ were prepared from reagent oxides (purity 99.9\%) of $\mathrm{PbO}, \mathrm{Nb}_{2} \mathrm{O}_{5}, \mathrm{ZrO}_{2}$ and $\mathrm{TiO}_{2}$. These powders were ball-milled for $50 \mathrm{~h}$ with $\mathrm{ZrO}_{2}$ balls as a milling media in a polyethylene pot. The mixing powder was calcined at $850^{\circ} \mathrm{C}$ for $6 \mathrm{~h}$ in air and ball-milled again for 50h. The calcined PZT powder was pressed into dis$\mathrm{ks}$ and, then sintered at $1150^{\circ} \mathrm{C}$ for $2 \mathrm{~h}$ in air to obtain dense PZT samples. $\mathrm{ZnO}$ ceramics $(\mathrm{ZnO}+0.2 \mathrm{~mol} \%$ $\mathrm{Li}_{2} \mathrm{O}+10 \mathrm{~mol} \% \mathrm{NiO}$ ) was prepared from powders (purity 99.9\%) of $\mathrm{ZnO}, \mathrm{LiNO}_{3}$ and $\mathrm{NiO}$. These starting materials were ball-milled for $8 \mathrm{~h}$ and calcined at $600^{\circ} \mathrm{C}$ for $5 \mathrm{~h}$ in air. The calcined powder was pressed into disks under $50 \mathrm{MPa}$.

The dense PZT and press-formed $\mathrm{ZnO}$ disks were stacked and hot-pressed together in air at $700^{\circ} \mathrm{C}$ for 1h under $8 \mathrm{MPa}$. Before hot-pressing, a small amount of glass frits (softening point: $630^{\circ} \mathrm{C}$ ) were applied to the interface between dense PZT disk and press-formed $\mathrm{ZnO}$ disk. The hot-pressed bulk was then cut into a test piece (with $6 \mathrm{~mm} \times 11 \mathrm{~mm} \times 1$ $\mathrm{mm}$ in size) consisting of dense PZT and porous $\mathrm{ZnO}$ plates which were both $0.5 \mathrm{~mm}$ in thickness. A dense PZT plate was cut off with $4 \mathrm{~mm} \times 10 \mathrm{~mm} \times 1 \mathrm{~mm}$ (thickness) in size from the hot-pressed bulk to measure its displacement induced by electric field and gas sensitivity. A porous $\mathrm{ZnO}$ plate also was cut off in the same manner to measure its gas sensitivity. Silver paste was applied and fired on PZT, and gold was sputtered on $\mathrm{ZnO}$, as ohmic electrodes.

\subsection{Measurement}

The electrical measurements were performed using an electrometer (Advantest Co., Ltd., Model R8340A) which has a constant voltage supply within. The DC electrical resistivities of the dense PZT plate and the porous $\mathrm{ZnO}$ plate were measured at $250^{\circ} \mathrm{C}$ under controlled gas atmosphere, separately. Air, air-balanced $0.40 \mathrm{vol} \% \mathrm{H}_{2}$ gas and air-balanced $0.40 \mathrm{vol} \% \mathrm{CO}$ gas were used as testing gases, and 
gas flow rate was fixed at $3.33 \times 10^{-6} \mathrm{~m}^{3} / \mathrm{s}(200 \mathrm{cc} /$ min). Mechanical displacement was measured at $250^{\circ} \mathrm{C}$ in the direction perpendicular to electric field (along the length direction) using a strain gauge (Tokyo Sokki Kenkyujo Co., Ltd., Type ZFLA-I002LE) attached on the PZT side of $\mathrm{PZT} / \mathrm{ZnO}$ actuator, under an electric field of $0-250 \mathrm{kV} / \mathrm{m}$ in various atmospheres. Mechanical displacement of single PZT plate was also measured under an electric field of $500 \mathrm{kV} / \mathrm{m}$.

\section{Results and discussion}

\subsection{Structure}

A schematic illustration of the actuator, prepared in the present study, is shown in Fig. 1. Table 1 shows the relative densities and average grain sizes of dense PZT and porous $\mathrm{ZnO}$ plates those were cut off from stacked body. The distinct differences in density and grain size were observed between two plates.

\subsection{Gas sensing property}

The porous $\mathrm{ZnO}$ ceramics showed a high electrical resistivity of about $2 \times 10^{8} \Omega \cdot \mathrm{m}$ at $250^{\circ} \mathrm{C}$ in air, which was a little higher than that of dense PZT ceramics at the same temperature. Figure 2 shows gas sensing properties of porous $\mathrm{ZnO}$ and dense PZT plates, measured at $250^{\circ} \mathrm{C}$ under application of $10 \mathrm{~V}$ d.c. The porous $\mathrm{ZnO}$ ceramics added with $\mathrm{Li}_{2} \mathrm{O}$ and $\mathrm{NiO}$ showed a large decrease in resistivity by $\mathrm{CO}$ or $\mathrm{H}_{2}$ gas. Especially, in $0.40 \mathrm{vol} \% \mathrm{CO}$ gas, the decrease in resistivity reached more than one and half orders of magnitude. In contrast, electrical resistivity of dense PZT was kept constant in both 0.40 vol $\% \mathrm{H}_{2}$ and $\mathrm{CO}$ gases. As a result, electrical resistivity of $\mathrm{ZnO}$ became much lower than that of dense PZT in reducing gas atmospheres.

\subsection{Displacement characteristics}

Under application of electric field, piezoelectric ceramics expand in the direction of applied electric field and shrink in the direction perpendicular to applied electric field. Figure 3 shows the displacement

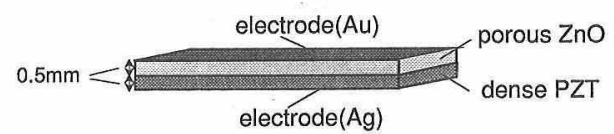

Fig. 1. A schematic illustration of actuator.

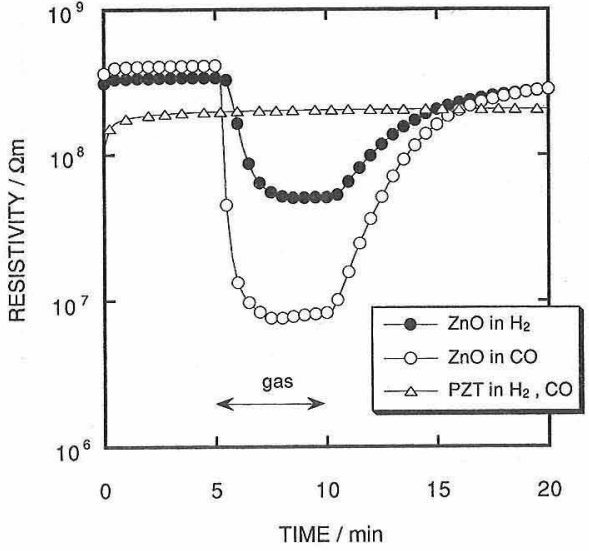

Fig. 2. Resistivity changes of porous $\mathrm{ZnO}$ and dense $\mathrm{PZT}$ by $\mathrm{CO}$ and $\mathrm{H}_{2}$ gases at $250^{\circ} \mathrm{C}$.

Gas concentration is 0.40 vol\% balanced with air.

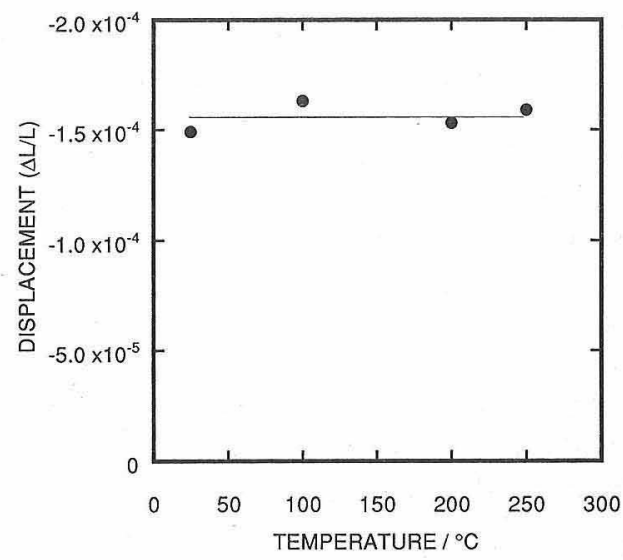

Fig. 3. Displacement of PZT plate as a function of temperature at $500 \mathrm{kV} / \mathrm{m}$.

of single dense PZT plate at $500 \mathrm{kV} / \mathrm{m}$ in air as a function of temperature. Here, mechanical displacements were represented by a ratio of the change to the original length $(\Delta L / L)$. Generally, PZT ceramics do not exhibit good electrostrictive characters at high temperatures near the Curie point $\left(375^{\circ} \mathrm{C}\right)$. However, it was confirmed that the present PZT ceramics kept a stable displacement in the direction perpendicular to electric field up to $250^{\circ} \mathrm{C}$.

Figure 4 shows the values of mechanical displacements at the PZT side of the actuator as a function of applied electric field in various atmospheres. The dis-

Table 1. Relative Density and Average Grain Size of Dense PZT Plate and Porous $\mathrm{ZnO}$ Plate

\begin{tabular}{ccc}
\hline Specimen & Relative density & Average grain size \\
\hline $\begin{array}{c}\text { Dense PZT plate } \\
\left(\mathrm{Pb}_{0.995} \mathrm{Nb}_{0.01}\left(\mathrm{Zr}_{0.53} \mathrm{Ti}_{0.47}\right)_{0.99} \mathrm{O}_{3}\right)\end{array}$ & $98 \%$ & $5.0 \mu \mathrm{m}$ \\
\hline $\begin{array}{c}\text { Porous } \mathrm{ZnO} \text { plate } \\
\left(\mathrm{ZnO}+0.2 \mathrm{~mol} \% \mathrm{Li}_{2} \mathrm{O}+10 \mathrm{~mol} \% \mathrm{NiO}\right)\end{array}$ & $51 \%$ & $0.4 \mu \mathrm{m}$ \\
\hline
\end{tabular}




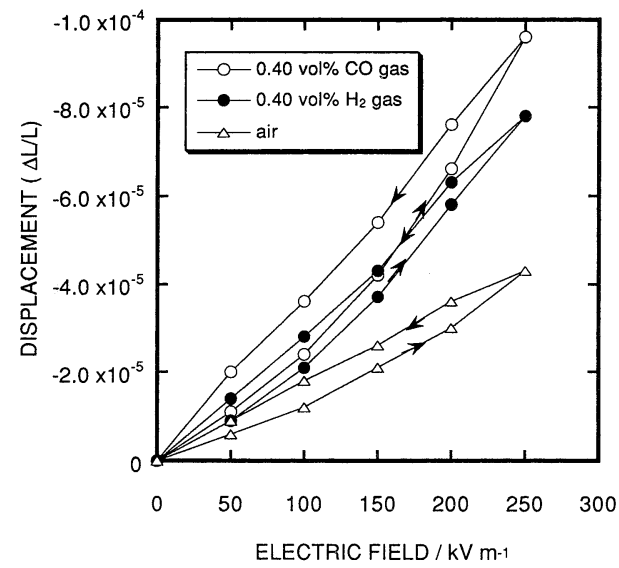

Fig. 4. Displacements at PZT side of $\mathrm{PZT} / \mathrm{ZnO}$ actuator as a function of applied electric field at $250^{\circ} \mathrm{C}$ in various atmospheres.

placements almost in proportion to the induced electric field were observed in the measured electric field range. The values of displacements were larger in the order of those in $\mathrm{CO}, \mathrm{H}_{2}$ and air.

In air, both of the dense PZT and the porous $\mathrm{ZnO}$ parts have high resistances in an almost same level and hence the applied d.c. voltage is distributed to the both parts. However, in reducing gas atmospheres, resistance of the $\mathrm{ZnO}$ part becomes smaller than that of the PZT part. This leads to an concentration of applied voltage to the PZT part. Consequently, the value of shrinkage would be larger in reducing gas atmosphere than in air. It is reasonable that the shrinkage was larger in $\mathrm{CO}$ gas than in $\mathrm{H}_{2}$ gas, because a decrease in resistivity of the porous $\mathrm{ZnO}$ plate was larger in $\mathrm{CO}$ gas than in $\mathrm{H}_{2}$ gas.

Measurement of bending displacement was tried on the present actuator fixed at one end, using noncontact laser sensor. The value of bending displacement was approximately $4-12 \mu \mathrm{m}$ under an electric field of $250 \mathrm{kV} / \mathrm{m}$ at $250^{\circ} \mathrm{C}$ in reducing atmospheres.
However, correct values of bending displacement have not been measured yet because of difficulties of non-contact measurements at high temperatures. From the results of shrinkage, the value of bending displacement is also expected to increase by introduction of reducing gases.

From the present results, it is suggested to be possible to fabricate an actuator responding to reducing gases, provided that a PZT plate is combined with a ceramic material having a high resistivity in air and a good gas sensitivity. The addition of $\mathrm{Li}_{2} \mathrm{O}$ and $\mathrm{NiO}$ was found effective to give such properties to porous $\mathrm{ZnO}$.

\section{Conclusions}

(1) The porous $\mathrm{ZnO}$ ceramics $\mathrm{ZnO}+0.2 \mathrm{~mol} \%$ $\left.\mathrm{Li}_{2} \mathrm{O}+10 \mathrm{~mol} \% \mathrm{NiO}\right)$ showed a high electrical resistivity $\left(2 \times 10^{8} \Omega \cdot \mathrm{m}\right)$, which was higher than that of dense PZT ceramics in air at $250^{\circ} \mathrm{C}$, and exhibited large decreases in resistivity by $\mathrm{CO}$ and $\mathrm{H}_{2}$ gases.

(2) The values of shrinkage by a d.c. voltage at $\mathrm{PZT}$ side of the $\mathrm{PZT} / \mathrm{ZnO}$ actuator was larger in reducing gas atmospheres than in air. It is supposed that the applied voltage is concentrated to the PZT part by introduction of reducing gas due to a decrease in resistance of the $\mathrm{ZnO}$ part.

(3) The bending displacement of the actuator was also observed in reducing gas atmosphere, although the precise value was not obtained due to the high temperature in measurements.

References

1) H. Asakura, H. Yamamura and K. Uchino, Ferroelectrics, 93, 205-10 (1989).

2) Y. Isogai, M. Miyayama and H. Yanagida, J. Ceram. Soc. Japan., 102, 537-40 (1994).

3) H. Yanagida, Ferroelectrics, 102, 251-57 (1990).

4) T. Seiyama and S. Kagawa, Anal. Chem., 38, 1069-73 (1977).

5) M. Takata and H. Yanagida, Yogyo-Kyokai-Shi, 87, 19-27 (1979). 